\title{
Political Language of Young People on the Demonstration of September 24, 2019
}

\author{
Airin Miranda ${ }^{1}$, Diah Kartini Lasman ${ }^{2}$, Assyifa Indira Gunawan Putri ${ }^{3}$ \\ \{mirandaairin@gmail.com ${ }^{1}$, deka.lasman@gmail.com ${ }^{2}$, assyifaigp@gmail.com ${ }^{3}$ \} \\ Universitas Indonesia, Indonesia ${ }^{1,2,3}$
}

\begin{abstract}
Demonstration is a way of expressing an opinion in a democratic country and every citizen has the right to voice his opinion. Student demonstrations in front of the Parliament building on September 24, 2019 were often compared to the demonstrations of their predecessors in 1998 in terms of the purpose and manner of different demonstrations, including the use of language. This can be seen from the poster that contains messages that are called on by students as can be seen in various social media accounts and in newspapers. The poster that was brought in this demonstration was even highlighted in the media, both in print, television and social media. This study examines the posters using Jacobson's communication theory and critical discourse analysis to see how students voice their political aspirations. Through this research it was found that students associate political issues with personal problems through their messages on posters. Also, the message they convey is humorous and ignores Indonesian language rules.
\end{abstract}

Keywords: Language, Student Demonstration, Critical Discourse Analysis, Demonstration Posters, Denotation-Connotation Meaning

\section{Introduction}

Language is a communication tool to convey a message. In linguistics, this level of communication involves speaker and interlocutor. The interlocutor is not limited to individual but also can be an organization or a body. On September 24, 2019, a student demonstration took place in front of the House of Representatives (DPR/MPR). In this demonstration, these students carried posters with various type of written expressions as their way of communication. Speakers in this context are students and their interlocutors are DPR/MPR bodies/agencies. The posters brought by these students became further discussion both in the media and on social media. Harian Kompas (daily newspaper) on Thursday, September 26, 2019 raised an article entitled "The Art of Resistance of Young Children Behind Funny Demonstrator Posters" that gave extended comment and examples of posters brought in the demonstration. According to this article, the posters contained elements of humor and sarcasm. Comments on these posters were also posted on the account Instagram @kemendikbud.ri. This Instagram account highlights Indonesian mistakes in the posters such as: "matikan saja mantan ku" (just kill my ex). The word "mantanku (my ex)" should be connected, as in "mantanku" according to the rules of use of affix in Indonesian.

The posters which were discussed further as funny posters and contained errors in Indonesian language were tools for students conveying their aspirations regarding the bill made by the DPR. According to Roman Jakobson, any act of verbal communication is composed of six elements, or factors (the terms of the model): (1) a context (the co-text, that is, the other 
verbal signs in the same message, and the world in which the message takes place), (2) an addresser (a sender, or enunciator), (3) an addressee (a receiver, or enunciate), (4) a contact between an addresser and addressee, (5) a common code and (6) a message. Each factor is the focal point of a relation, or function, that operates between the message and the factor. The functions are the following, in order: (1) referential ("The Earth is round"), (2) emotive ("Yuck!"), (3) conative ("Come here"), (4) phatic ("Hello?"), (5) metalingual ("What do you mean by 'krill'?"), and (6) poetic ("Smurf”). When we analyze the functions of language for a given unit (such as a word, a text or an image), we specify to which class or type it belongs (e.g., a textual or pictorial genre), which functions are present/absent, and the characteristics of these functions, including the hierarchical relations and any other relations that may operate between them [1].

Taking the example of one of the posters highlighted by Harian Kompas and referred as a funny poster, it is written: "Cukup cintaku yang kandas, KPK jangan. (It is enough that my love life hit rock bottom, the KPK should not)". The receiver of this message is KPK, a public institution, not a friend or anyone from the sender's private space. Thus, we see an emotive function, which means the message is closely related to the inner atmosphere of the speaker. In addition to Kompas and Kemendikbud Daily, several online news sites such as Detik News and Instagram account @ viceind also raised the same thing. Detik news made an article entitled "Melihat Lagi Tulisan-tulisan Lucu di Spanduk Aksi Mahasiswa (Observing Funny Writings on Student Action Banners)". While Vice Indonesia presented a series of posters as news illustrations about this demonstration. The language used in these posters, in addition to being seen its function can also be interpreted by seeing the explicit meaning behind the implied message.

Some media can conclude that the posters in this student action are funny because they see the connotative meaning contained in the written message. For example, a poster raised by Detik News reads: "Ternyata DPR udah jago bikin undang-undang yang user friendly. Friendly for Koruptor (It turns out that the DPR is already good at making laws that are user friendly. Friendly for Corruptors)". The denotation meaning of the word "jago" used here is "expert", which is a compliment. Then the term "user friendly" is also has a positive meaning, as if the DPR were already very skilled in making laws that was appropriate for the community as a user. However, the concept is then juxtaposed with the word "corrupt", so that the positive impression obtained from the first statement disappears immediately replaced with a negative impression. This impression is included in the level of connotative meaning, and this contrast between the denotative-connotative meaning is read as a funny message or the art of resistance by the media.

The posters that appeared in the student demonstrations on 24 September 2019 were seen displaying the dynamics of language. This research will raise this dynamic with Jakobson's language function theory to see the dominant function of the messages raised and understand the contents of the message using the critical discourse analysis model from Fairclough [2].

\section{Methodology}

\subsection{Research Methods}

Qualitative research methods are used in this study. Qualitative research aims to explain a phenomenon in depth with a relatively small number of research objects. In addition, this type of research is also conducted to describe the reality that is happening within a certain time [3]. 
Added by Moloeng [4], this research method can be used to understand behaviors, perceptions, motivations, actions, etc. that occur in a phenomenon by means of descriptions in the form of words. Based on that explanation, it is deemed appropriate to use qualitative methods to understand the political language of young people in this 2019 student demonstration.

\subsection{Data Sources}

Data sources used are secondary data sources obtained from various online news portals, social media accounts, public news agencies and government agencies. The corpus is limited to photos of posters raised by Kompas Daily, Detik News, Instagram accounts @ kemendikbud.ri and @ viceind. The corpus is collected from these sources with the aim of obtaining a corpus that can represent judgments and highlights from a variety of different sources, both state and private institutions.

\subsection{Data Collection Techniques}

Data collection was carried out in a literature study. That is, the corpus was obtained not from a primary source but rather was collected from various online media that had collected poster photos taken by students while carrying out their actions. From the photos of posters collected will be examined the use of language in the poster text.

\subsection{Data Analysis Techniques}

Using Jacobson's communication theory [1], this research will identify six communication factors and find the function of the language used. Furthermore, researchers will look for the meaning of the messages contained therein using the theory of denotation and connotation from Barthes [5]. Barthes said that messages can have denotative and connotative meanings. Denotation is the meaning that is formed from the unity of language that refers to information that comes from outside the language. Denotation is the process of meaning with the same mechanism as referential. In its meaning, denotation has a reference that points to a nonlinguistic reality (not language). Meanwhile connotation is the meaning that comes from the impression of the recipient of the message. The connotative meaning is an added value that will always be present because of the denotative meaning. Connotative markers vary greatly, namely sound, writing, sound pressure, rhythm, syntactic structure. The marker can also be in the form of words, phrases, clauses, utterances contained in the level of expression or content. Starting from the hypothesis that the message conveyed through the student action posters uses emotive language functions and humorous content, then the analysis will also be carried out using critical discourse analysis.

As said by Fairclough [2], critical discourse analysis is an activity linking language and social or community context. Language cannot stand alone and inevitably gets influence from social relations and social context. Therefore, in critically analyzing texts, in addition to paying attention to linguistic aspects, it is also mandatory to pay attention to social structures that affect the sender, recipient, and message content to find representations, relationships, and identities of actors in communication that occur in a text. 


\section{Findings and Discussion}

\subsection{The Voice of Young People}

Through analysis using Jacobson's communication theory and critical discourse analysis, this study shows the language functions used in student demonstration posters as well as the ignorance of Indonesian language rules performed by students. Furthermore, it was later shown that through the demonstration poster students showed the use of distinctive language in responding to political phenomena in Indonesia.

\subsubsection{Private/Everyday Life of Message Sender}

Of the seven-corpus analyzed there were four which indicated that the message conveyed was associated with the private life of the sender of the message. This can be seen from the poster titled Jangan matikan keadilan! Matikan saja mantanku! (Don't kill justice! Just kill my ex), Kesini karena panggilan hati. Bukan sekedar kebutuhan insta story! (My heart tells me to come here. Not just for my Insta Story!), Negara ini darurat! Stop push rank! (Our country is in an emergency! Stop push rank!), dan Cukup cintaku yang kandas, KPK jangan! (I'll let my love to fail, but not KPK!), will then be mentioned as figure 1, figure 2, figure 3, and figure 5 .

Messages with a personal life content are indicated from the use of diction that is typical of young people's lives relating to love life, activities on social media, and the fondness of playing online games. Here is the first corpus analysis with the title Jangan matikan keadilan! Matikan saja mantanku! (Don’t kill justice! Just kill my ex).

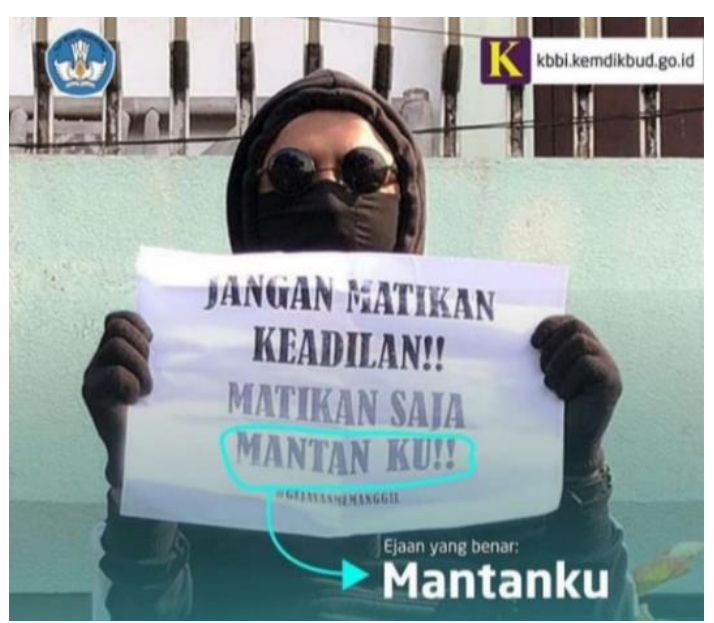

Fig. 1. Instagram kemdikbud.ri. 


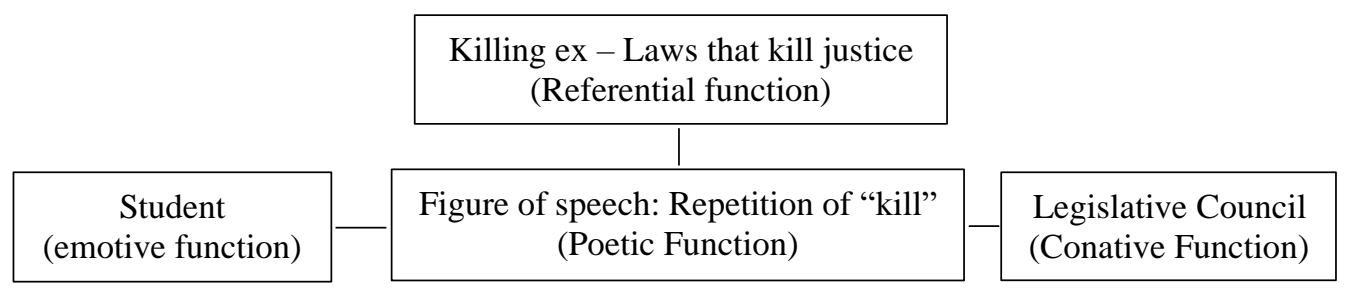

Sender: student

Receiver: Legislative council

Context: Killing ex - Laws that kills justice

In the diagram above, emotive and poetic functions dominate the message displayed in the sentence. In the referential function, the sender compares the message with his private life. This message serves to give commands to the receiver to stop their actions. The poetic function is displayed by repeating the word "matikan (kill)". According to the KBBI, the word "matikan (kill)" has the meaning of eliminating, crippling, extinguishing, freezing, and destroying. This word is also included in words used in everyday language and commonly used to govern. The use of punctuation exclamation (!) Supports the command being delivered. The election of the "exes" diction brought the problems of the people carried by the demonstrators into private space. The big issues that concern the wider community are represented by their "exes" which means "ex-lovers". The ex-lover has the meaning of a grim past, disloyalty, bad memories, so asked to be "killed". The emphasis of " $k u$ (me)" on the word "ex" shows which ex they mean, i.e., ex-demonstrators or more narrowly, ex poster lover. Once again this shows the private space that is used as a reference in public space, in this case, refers to the country's problems.

The second corpus with the title Kesini karna panggilan hati. Bukan sekedar kebutuhan insta story! (My heart tells me to come here. Not just for my Insta Story!) indicates the use of diction related to activities on social media.

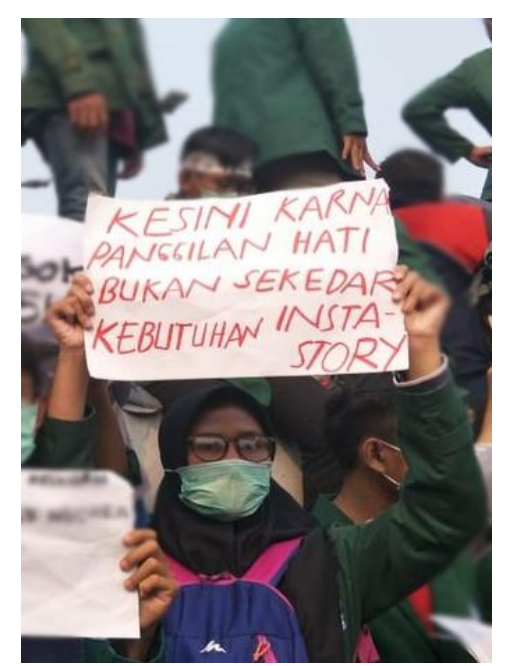

Fig. 2. Kompas.com "Memaknai Poster Saat Demo Mahasiswa yang Bikin Senyum, Cermin Politik Nirkekerasan". 
Come here because of a call of heart - student action is real action (Referential function)

\begin{tabular}{|c|c|}
\hline $\begin{array}{c}\text { Student } \\
\text { (Emotive function) }\end{array}$ & $-\begin{array}{c}\text { Figure of speech: personification } \\
\text { "heart called" dan "insta story needs" } \\
\text { (Poetic function) }\end{array}$
\end{tabular}$-\begin{gathered}\text { DPR } \\
\text { (Conative Function) }\end{gathered}$

Sender: student

Receiver: DPR

Context: come here because of a call of heart - student action is real action

Emotional and poetic functions dominate the diagram above. The referential function in context is the personal aspiration of the message sender. This message serves to make the recipient of the message take seriously the action of the sender of the message. Conveying messages in sentences using personification style, "heart calls" and "insta story needs", makes this statement seem personal.

Heart calls are used in this poster because they want to show the purity of the demonstrators' intentions to carry out their actions. The personal impression that is carried also can be seen from the use of the word "insta story". Insta story is a feature of the Instagram social media application that is often used to inform the daily activities of Instagram users. Insta story is only 24 hours long and will be deleted from the user's account by the Instagram application so that it can no longer be seen by the public. Generally, Instagram users use Insta Story to tell their daily stories that are considered less important and less aesthetic to be enshrined on their Instagram account pages. Through the comparison between "heart calls" and "insta stories" used by students in the poster, it indirectly shows the seriousness of the actions they take. As explained earlier, insta story is generally interpreted as a forum to convey something that is not too important. This meaning makes the word "heart call" shows a sincerity of student action.

Both "heart calls" and "insta stories" are important in the personal lives of young people today. However, from this poster there is no element of humor but satire. In addition, the Poster also shows that young people currently do not pay attention to the spelling of language, this is seen from the error writing the word "ke sini" written "ke sini" by the sender of the message, regardless the usage of affix in Indonesian Language.

Next is the corpus titled Negara ini darurat! Stop push rank! (Our country is in an emergency! Stop push rank!) using diction related to playing online games.

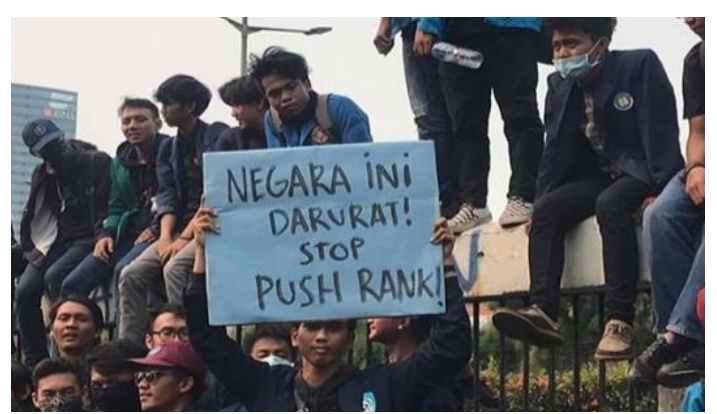

Fig. 3. Instagram @ viceind. 


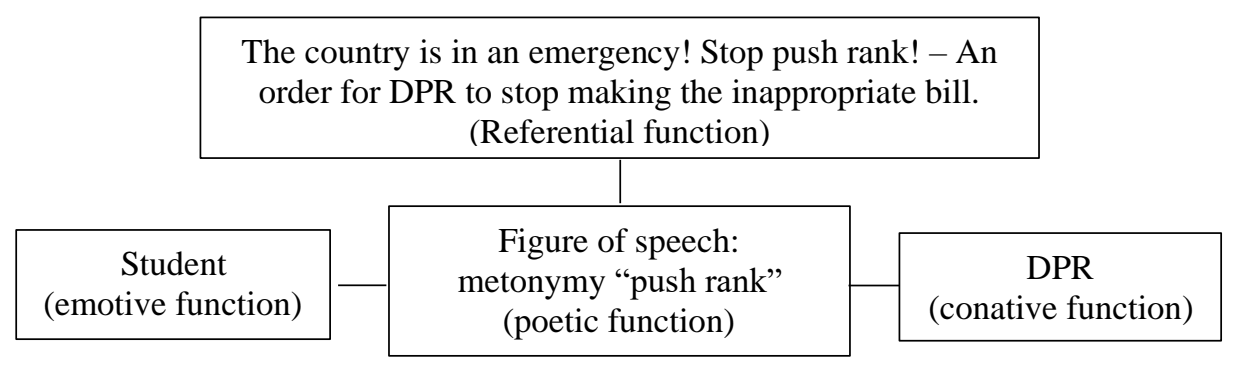

Sender: student

Recipient: DPR

Context: State of emergency, stop push rank - An order for the DPR to stop an inappropriate bill

The referential function which is the context is the private life of the message sender. The message is to give commands to the recipient of the message. Emotional and poetic functions dominate the message. The presentation of the message uses the metonymy speech on the word "stop push rank" because this word refers to information about Mobile Legend video games that are being played by gamers in Indonesia. Push rank is one of the actions in video games to increase levels of players. The players do "push rank" to increase popularity and even to benefit from its position in the game. It can be understood that in this poster's message, the DPR is considered to be busy seeking its own benefits by making decisions that are considered not propeople and benefit only some people.

The "stop push rank" diction that only some people understand makes the message delivered personal. The use of diction is more personal because it shows that students consider the representatives of the people as recipients of the message to be in the same environment as them, so they use words that are generally used in young people's life. This shows the relationship between poetic and emotive functions in the sentence.

The fourth poster also uses diction related to love life such as the corpus 1 . The text in the poster is Cukup cintaku yang kandas, KPK jangan! (I'll let my love to fail, but not KPK!).

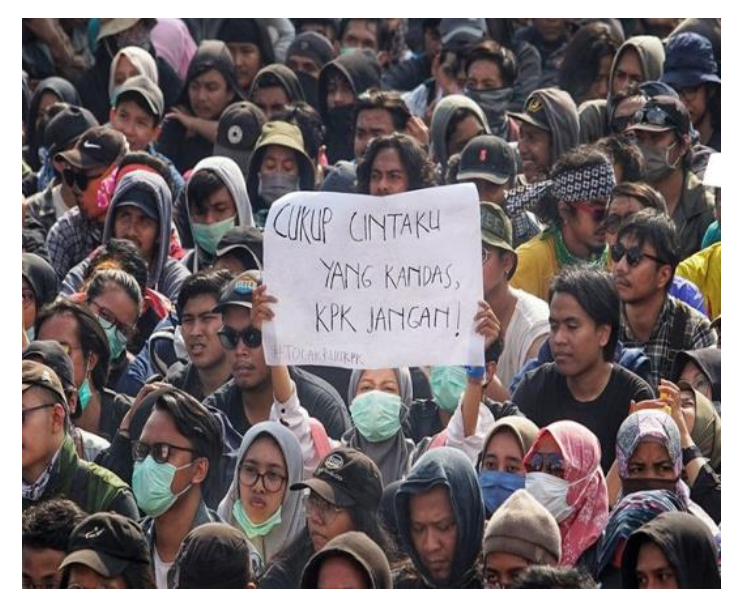

Fig. 4. Kompas.com "Seni Perlawanan Anak Muda di Balik Poster Lucu Pendemo". 


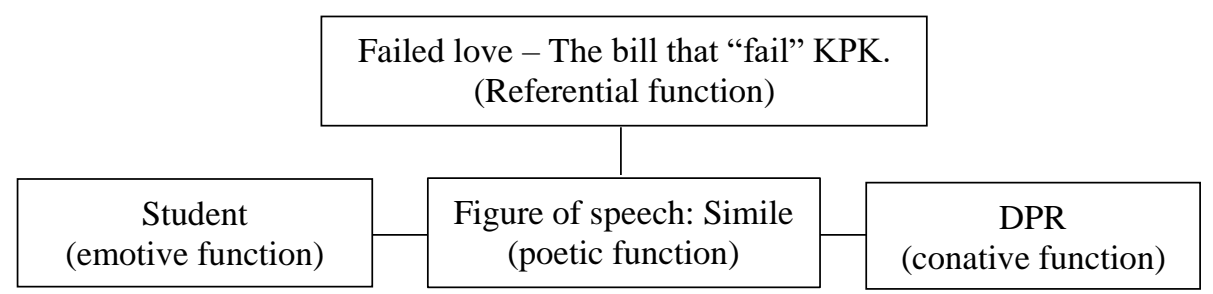

Sender: Student

Recipient: DPR

Context: Failed Love - The bill that "fail" KPK

In the diagram above it appears that the dominant functions are poetic and emotive. In the referential function the context is the private life of the message sender. This message serves to make the recipient of the message sympathetic to the circumstances conveyed. Thus, the conative function is also related to the emotive function, namely personal life. How to deliver it, which fulfills the poetic function is done by presenting the word "ran aground" which has a field of meaning destroyed, crashing, destroyed and not the words included in everyday language. The choice of diction also makes this statement more personal because the word "ran aground" seems very personal.

\subsubsection{Humorous Message}

In addition to messages that are personal, we also find that messages through posters are also loaded humor as in the following poster which contains the message for the DPR, DPR jangan minta dicubit (DPR, don't ask me to pinch you).

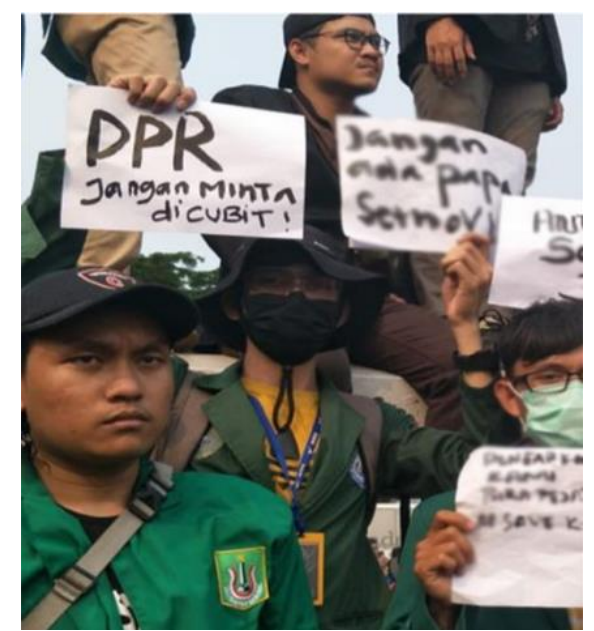

Fig. 5. Kompas.com “Memaknai Poster Saat Demo Mahasiswa yang Bikin Senyum, Cermin Politik Nirkekerasan". 


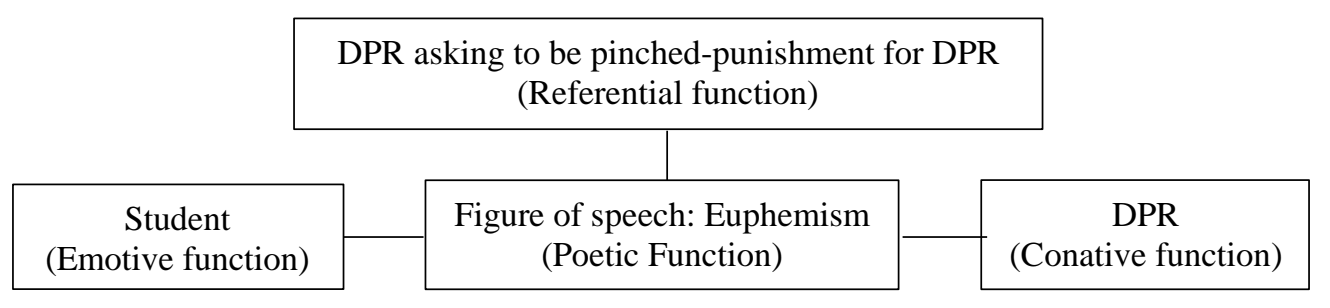

Sender: Student

Receiver: DPR

Context: DPR being pinched - punishment for DPR from the people

In the diagram above, the referential function that becomes the context is the private life of the message sender. Sender placed Receiver in private space, not in public space. This message serves to provide a threat to the recipient of the message. By using the language style of euphemism, the threat is refined by calling for punishment by pinching. In general adults give punishment to small children who act badly by giving them a pinch. Through this poetic function, it gives the impression that students portray the DPR like children who behave badly.

The use of diction "pinched" shows that the message contained in the poster contains humor because the message conveyed is not really about "pinching" the DPR, but there is an effort to refine the message to be conveyed, that is a threat that could affect the DPR's position in Parliament. The word "pinched" is like reminding the DPR of its minor position compared to the people who voted for it. So, the people may "pinch" or in this case correct or criticize members of the DPR. It also has implied message that says DPR is incapable of making laws, because by putting DPR in position of a child, it means that DPR behaves like one. It leads to interpretation that DPR has no capacity in making laws for the country, because a child is surely incapable of doing so. In addition, the use of the word "ask to be pinched" shows that there is an intention on the part of the DPR to make mistakes such as asking for punishment or asking attention from the people.

The same humorous message is found also from the text in poster shown in figure 6, cuti nonton Drakor karena di DPR lebih banyak drama ('I am' absent from Drakor because there is more drama in DPR).

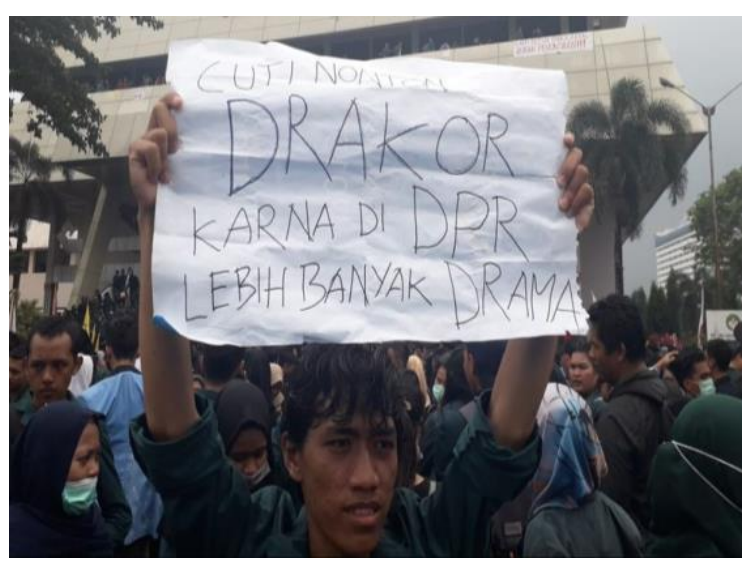

Fig. 6. Kompas.com “Demo ala Milenial, Tulisan Spanduk "Nyeleneh” yang Ngena Banget". 


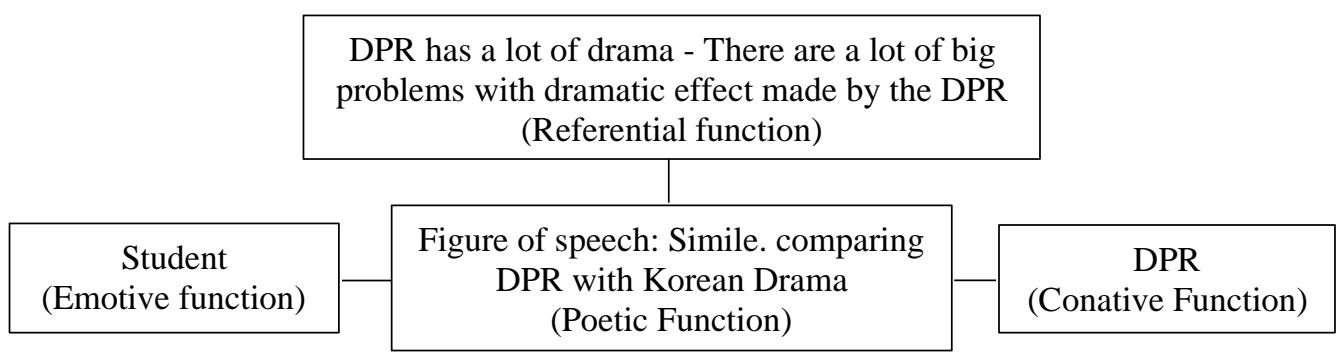

Sender: Student

Receiver: DPR

Context: DPR has a lot of drama - There are a lot of big problems with dramatic effect made by the DPR

In the diagram above, the dominant language functions are emotive and poetic functions. The referential function which is the context of the message is the private life of the message sender. The message stated that the problems created by the DPR are numerous, similar like the problems that appear in Korean television dramas. The message presentation uses a simile style that compares the DPR with stories in Korean drama. This shows that the emotive and poetic functions are interrelated. "Drakor" is an abbreviation of Korean Drama, a trending spectacle that has swept audiences from various circles in Indonesia. The choice of diction indicates that it is as if everyone understands the term "Drakor" and is familiar with it so that they can understand the message. In this case, the private space is again presented in public space while expressing opinion.

The use of the word "Drakor" creates an impression of humor in the message conveyed. Equating the DPR with Korean Drama shows as if the various decisions made by the DPR make a dramatic impression, even though what is meant by the sender of the message is the systemic effect given by the DPR's decisions to the Indonesian people in general. In addition to the element of humor in the poster, it was also found the writing error sentence structure that is: no subject in the sentence.

Humorous message also found in another poster shown in figure 1, Don't kill justice! Just kill my-ex. Here, the demonstrators called on the Legislative Council (DPR) not to kill "justice". The word "Keadilan (justice)" has a broader meaning and impact on people so it must be preserved or represented in this poster as "don't be killed". The use of non-standard words such as "kill" itself indicates an error in the use of Indonesian in this poster. The message has a touch of humor in this poster, because the message conveyed does not really ask the DPR to kill or "kill" the ex-lover, but instead tries to provide a comparison that shows disregard for the existence of his ex-lover over the justice expected from the law passed by the Parliament.

\subsubsection{Satirical Message}

There are other posters discussed earlier that show the content of satirical messages in it, namely the message in figure 2, kesini karna panggilan hati. Bukan sekedar kebutuhan Insta Story! (My heart tells me to come here. Not just for my Insta Story!). By comparing the "call of heart" and "insta story", the demonstrators want to emphasize their seriousness and the sincerity of their intention to fight for their goals.

The satirical message is also found in the poster in figure 3, negara ini darurat! Stop push rank! 
(Our country is in an emergency! Stop push rank!). The word "push rank" shows the appearance of satirical humor in the message. Through this word, DPR decisions seem to be mere games and are not necessary to be applied. This word also shows that non-functioning state institutions should be compared to people playing video games.

In the poster containing message Selain YouTuber, anak-anak ingin jadi koruptor (Beside being YouTubers, children want to be corruptor) we found satirical message conveyed to members of the Parliament.

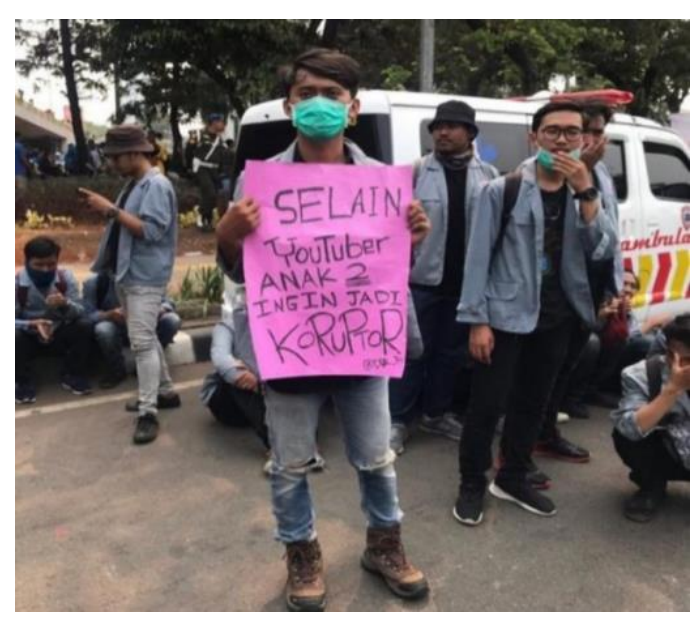

Fig. 7. Instagram @ viceind.

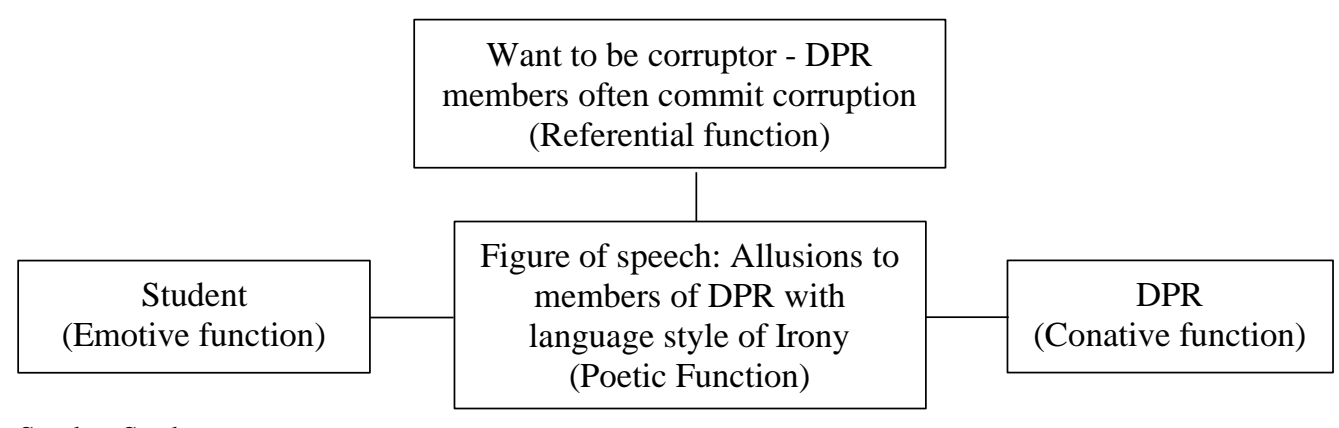

Sender: Student

Receiver: DPR

Context: Children want to be corruptors - DPR members often commit corruption

The language functions that dominate in the diagram above are the Emotive Function and the Poetic Function. The referential function which is the context in the text is the personal aspiration of the message sender. Poetic functions are presented using an irony style. The message that the writer wants to convey serves to provide a satire to members of the DPR. The use of the "YouTuber" diction which is close to the youth of today, makes the message more personal.

The use of the word "corruptor" provides an element of humor because the message conveyed is not really young people at this time aspiring to become corruptors. But to give a satire as well as to inform members of Parliament that the public is aware of acts of corruption 
that are often carried out by the Parliament. Apart from that, the implying message of this poster is also about how the young people aim for richness. Corruptor always brings the idea of someone who is very rich and they also make money very easy. These two elements can be found also in the term of "YouTuber". Many people now want to be a famous youtuber because this profession can make a lot of money in a short amount of time. Further than that, it is an open discussion whether the young people are very concern about materialistic things, compared to the previous generation.

\subsubsection{The Use of Non-Standard Indonesian Language}

In addition to the three findings above, we also find from this study the use of language Non-standard Indonesia, namely on corpus 1 and 2. On the poster in figure 1 Jangan matikan keadilan!! Matikan saja mantan ku! (Don't kill justice! Just kill my ex!). Following Pusat Bahasa [6] the last word "my ex" is written in an inappropriate grammar on the poster, "mantan ku". The possessive pronoun "my" ("ku" in Indonesian) as well as "your", "yours" etc. should be written as a set of words that precede it. Thus, the correct word should be "mantanku" and not "mantan ku". Likewise with the poster on figure 2 Kesini karna panggilan hati, Bukan sekedar kebutuhan Insta Story! (My heart tells me to come here. Not just for my Insta Story!). The word "kesini" should be written "ke sini" because "ke" is a preposition that marks the place. Writing the correct preposition according to Pusat Bahasa [6] is separate from the noun.

Poster in figure 2 also shown misspelling for the word "because" and "just". According to the Indonesian language standard, the word "because" is written "karena" and not "karna" and the word "just" is "sekadar" and not "sekedar".

\subsection{Discussion}

Through the analysis of several corpus using the Jacobson language theory described above, it can be concluded that the posters used by students at the 24 September 2014 action were dominated by messages that contained personal elements. The referential function contained in the poster used by students in the action tends to lead to the personal life experienced by young people. The style of language used also uses terms that are close to young people, such as YouTuber, Ex, Insta Story, Push Rank and Drakor. In the posters also found some errors in writing Indonesian spelling, showing that young people tend not to pay too much attention to the rules of language in conveying messages. In addition, foreign language interventions were also found in posters brought by students. There are also messages that are humorous and satirical in nature. From this it can be concluded that the political language of young people is more likely to be associated with personal life, so the message conveyed is personal.

Contrary to the informal and non-serious impression displayed by the student demonstrators, the contents of the message they conveyed meant a deep concern for the country's problems. Furthermore, it is interesting to observe the language style of young Indonesians today as a tendency to bring personal feelings into the public sphere. Today's young people are expressing and communicating by blurring the boundaries between public and private space. In giving examples or emphasizing messages they often use diction related to personal matters. The use of diction that is personal shows that as if all parties should understand the problems in their personal lives. The recipient of the message, in this case the DPR, is no longer important in the communication or delivery of their message because what is prioritized is the delivery of the message or the expression of the sender of the message. 


\section{Conclusion}

Critical discourse analysis conducted on this research shows that there is a change in the language style of young people today. The main trend is the delivery of messages in the public and formal sphere using an informal personal approach. This is also shown by the spelling mistakes and diction choices that are personal or not well known. The recipient of the message is no longer a consideration in the delivery of aspirations, as well as the success of the delivery of the message, on the contrary the expression of the sender of the message is very important so that there are no fixed rules governing their language style. Appropriately, it can be said that through the text in the demonstration posters dated September 24, 2019, young people now have a new communication model that ignores differences in formal and informal speech as well as the public and private spheres.

\section{References}

[1] R. Jakobson, "Linguistics and poetics," in Style in language, MA: MIT Press, 1960, pp. 350-377.

[2] N. Fairclough, Language and power. Pearson Education, 2001.

[3] R. Kriyantono, Teknik praktis riset komunikasi. Prenada Media, 2014.

[4] L. Moleong, Metodologi Penelitian Kualitatif. Bandung: PT. Remaja Rosdakarya, 2010.

[5] R. Barthes, "Elements of Semiology," Transl. by Annette Lavers Colin Smith). London Jonathan Cape, 1964.

[6] Pusat Bahasa, Pedoman Umum Ejaan Bahasa Indonesia yang Disempurnakan. 2000. 